\title{
ファイバレーザーの基礎と将来
}

\author{
植田 憲一 \\ 電通大レーザー新世代研究センター（テ182-8585 東京都調布市調布ヶ 丘1-5-1）
}

\section{The Prospects of High Power Fiber Lasers}

\author{
Ken-ichi UEDA \\ Institute for Laser Science, 1-5-1 Chofugaoka, Chofu, Tokyo 182-8585
}

(Received October 30, 2000)

\begin{abstract}
Double clad fiber lasers open the new world of high power lasers for industrial applications with high beam quality power delivering. The physics in the absorption process of double clad fiber is described related to the spatial hole burning effect. The homogeneous absorption is essential to achieve high saturation power. The basic physics of fiber lasers is described in a manner of general physics of lasers. A fiber-embedded disk in a side pumping scheme is proposed from the basic principle. The fiber disk laser is promising for the $\mathrm{kW}$ output from a single fiber with multimode core. A photonic fiber is introduced as a future model of high power and high performance fiber lasers.
\end{abstract}

Key Words: Fiber lasers, Double clad pumping, Laser diode pumping, Fiber disk, Photonic fiber

\section{1.まえがき}

ファイバをレーザー増幅媒体やレーザー発振器の対象 として考えることは, 1980年代の後半1)になって考案さ れ,始めて現実的なものとなった。そして,110Wの出力が 報告2)されるにいたって, 高出力レーザーとして大きな可 能性を持っていることが広く認識されるようになった. 10 ミクロン以下という極小のコアを持つ光ファイバは, 信 号伝送の手段とは考えられても, 高出力レーザーやエネル ギー伝送の手段とは考えられてこなかった。しかし,レー ザー発振器や増幅器の物理からすると, 超低損失という特 性は高出力レーザーにとって最も重要な性質であり, 高出 Jに问かない, というのは, 科学的根拠に基づかない単な る思いこみであった. 最先端の科学技術の分野でも, 様々 な思いこみ, 常識が発展を阻害することが起こりうるひと つの証拠である. 本論文では, 光通信以外の分野に応用さ れる高出力ファイバレーザーの原理と特徴を見直し, その 将来について検討する。

\section{2. 二重クラッドファイバレーザーの励起光吸収}

高出力ファイバレーザーを実現した最大の技術的進歩 は, Fig.1に示した2重クラッドファイバとクラッド励起の 開発である．励起用LDのビームは第1クラッド内をマルチ モード伝播し, 次第に中心コアに吸収されて減衰する。こ の結果, ファイバレーザーはクラッドとコアの断面積比に 量子効率をかけたパワー圧縮を実現でき, 空間パワー密度
で効力が決まるような産業応用分野に有用なレーザーと なる．長大な利得長を持つファイバレーザーは発振が容 易で両端4\%のフレネル端面反射で十分である。このた め, ファイバレーザーにとって, 最も重要な機構は, 効率よ い吸収システムであり,コアが励起光を吸収さえすれば, 高 効率発振は自動的に行われる。

高出力ファイバレーザー用の第1クラッドでは光通信の ような同軸円形断面は不適切となる。なぜなら, 円形同軸 2重クラッドファイバでは, 励起光吸収に横モードの空間的 ホールバーニングが生じるからである．Fig.2は第1クラッ ド内をジグザグ状に伝播している励起ビームを断面方向 から描いたものだが，断面内の反射の法則(入射角=出射 角) から, 円周上で反射するすべてのビームは, 光軸からの 距離を一定に保つ.すなわち, 最初にコアに入射する光線 は, 反射してもコアを照射し続けるので, 効果的に吸収さ

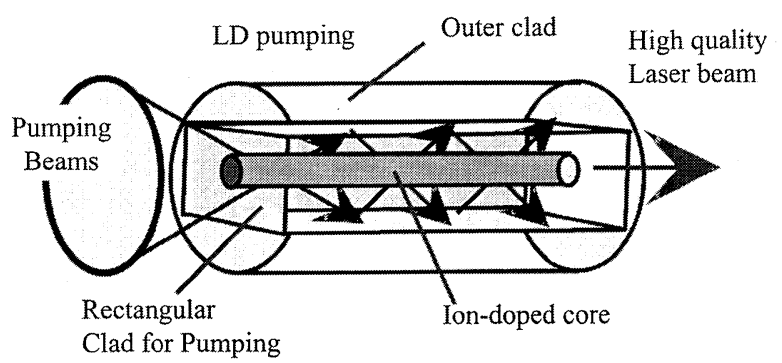

Fig.1 The double clad fiber laser compresses the beam brightness by pumping LD beams into the high quality laser output from the fiber core. 


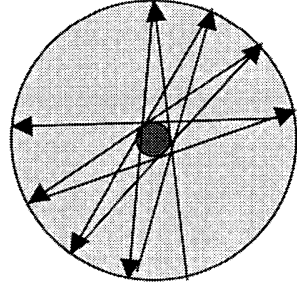

On-axis mode

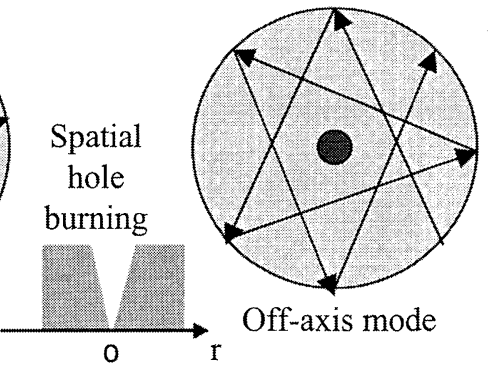

Fig.2 Spatial hole burning effect in the pumping absorption of circular fibers.

れ，すぐになくなってしまう。一方, 最初にコアを外れた 光線は、いくら反射を重ねても,コアに遭遇することはな く, 吸収されない。もし, 断面上に照射される励起光が完 全に均一で, 光線方向も均等だとすると,ほとんどの光は 吸収されずにファイバを通過する。この機構をファイバ 伝播のモードで表現すると,マルチモードファイバの伝播 モードの多くが, 中心部分にモードパターンのピークを 持っていないので,細いファイバコアとのモード整合が悪 く,吸収係数が小さいということになる。コアが中心を外 れた軸外れファイバ系を含む, 実際の吸収飽和レベルの詳 しい解析は, 参考論文3)を参考にされたい.

矩形断面の場合 (Fig.3)を考察しょう. 矩形断面の1点か ら入射した光線は, コーナーの直角を考慮すると,4回の反 射をして,元と同じ方向に伝播するときには, $\Delta y=2(a \tan \theta$ - $b$ ) だけの平行移動をする。すなわち, 中心コアとの距離 でいうと, $\Delta y \cdot \cos \theta=2 \cos \theta(a \tan \theta-b)$ となって, 入射点 $\left(x_{0}\right.$, $\left.y_{0}\right)$ とは無関倸になる。例外としては, $\Delta y=0$ の時, すなわ ち矩形断面内で同じ場所を通る共振モードを取った場合 であるが,それは確率としてほとんどゼロである，入射点 の位置にかかわらず，一定の速度で平行移動するというこ とは, 入射光線はすべて平等に吸収されることを意味し,完 全な均一吸収系であることを意味する。したがって,矩形 断面の 2 重クラッドノァイバは円形同軸ファイバと対照的 な均一吸収系だと理解できる。ささらに, D断面形状なども よく用いられるが,これらも変形断面内に, 平面反射系を 導入することで,ビームを平行移動させ, それによって効 果的なモード変換を実現している。矩形断面が均一吸収 の理論極限だとしても,それがもっとも効率的だというこ とを意味しない，実際にはD型断面,花びら型などいろい

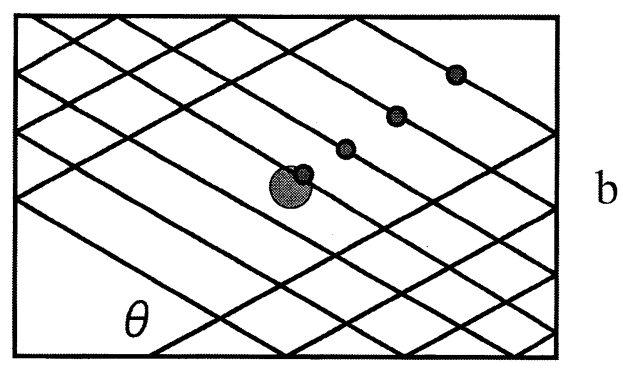

a

Fig.3 Shifting rate of pumping beams is constant for rectangular clad fiber lasers.
ろな形状が試みられ,いずれも大差ない吸収効率を実現し ている.

以上の考察を発展させると,均一吸収系を実現できるな らば, その実効的吸収係数は, コアの吸収係数を $\alpha$,コアと クラッドの断面積を $A_{\text {core }}, A_{\text {clad }}$ として $\alpha_{\text {eff }}=\alpha A_{\text {core }} / A_{\text {clad }}$ とな る. 2 重クラッドファイバを束ねたマルチコアファイバの 場合も, コア・クラッドの断面積比は同じなので, 前述の 関係は成立する。

したがって,ファイバレーザーの最も重要なパラメータ は, 吸収係数の大小ではなく, Fig.4に示したように, 吸収飽 和することなく,すべての励起光を吸収できるかどうかだ ということが分かる.

励起光を完全に吸収するには, $A_{\text {clad }} / A_{\text {core }}$ 倍の長さが必要 になる. 典型的な例では, クラッドとコアの断面積比は 1000 倍であり, コアが $5 \mathrm{~cm}$ の吸収長を持つ濃度では, $50 \mathrm{~m} の$ 長さのファイバレーザーが励起光を完全に吸収する，伝 播損失のほとんどないファイバレーザーはわずかの フィードバックでレーザー発振をするので, 共振器を構成 するのはファイバ端面の表面反射である，実際に実験を 行った結果をFig.5に示した。レーザー発振の波長に対す る高反射率ミラー(HR)をつけて片側から出力させた場

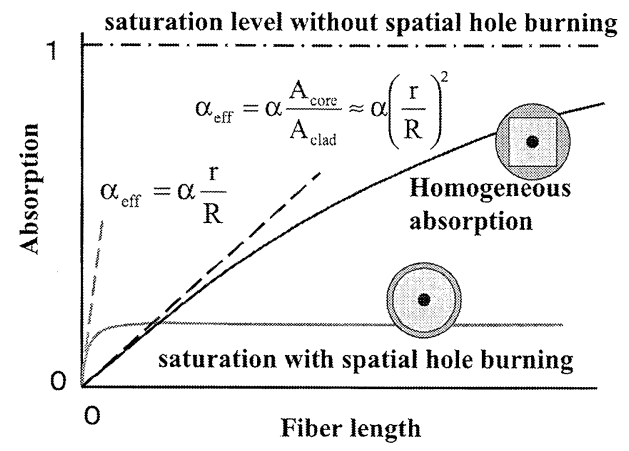

Fig.4 Saturation level is most important for the absorption process of fiber lasers.

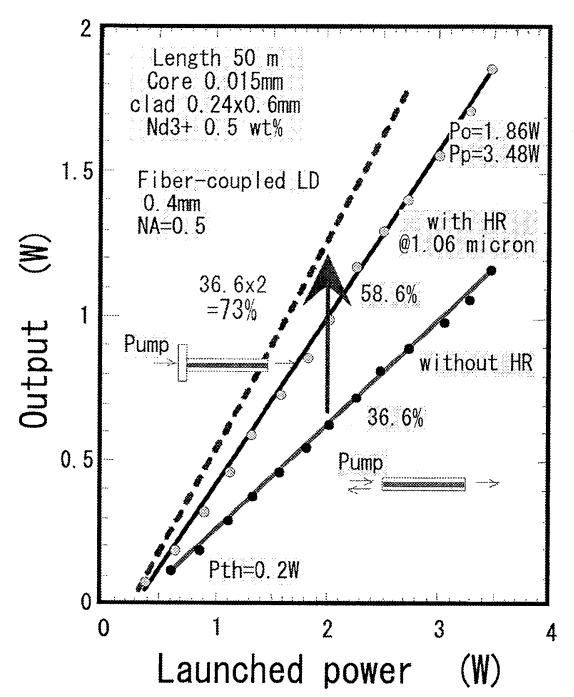

Fig.5 Laser performance of clad pumped fiber lasers. Maximum extraction efficiency of $73 \%$ is close to the quantum defect of Nd-ion of $76 \%$. 
合, 58.6\%のスロープ効率で発振した ${ }^{4)}$. 発振しきい值 $\left(P_{\mathrm{th}}\right)$ は200mWでファイバレーザーの損失は少ない。両側をフ レネル反射のみにした場合, 一方向から $36.6 \%$ の効率の出 力, すなわち, 両端の出力を合計すると $73 \%$ のスロープ効率 でレーザー光はレーザー媒質からエネルギーを引き抜い た. Ndイオンの量子効率が76\%であることを考えると,ほ とんど理想的にレーザー発振光にエネルギーが移行し た。出力 $\left(P_{\mathrm{o}}\right)$ は $1.86 \mathrm{~W}$ と少ない. しかし, これは世界最高 効率の発振であり,LDを増強して大きなパワーで励起すれ ば高出力が出ることは当然である。この時, 励起光はク ラッドを均一照射する低品質ビームで, 励起光からレー ザー発振までの輝度圧縮率は700倍以上であった。パワー 密度は $100 \mathrm{MW} / \mathrm{cm}^{2}$ 上回るので, 誘導ラマン散乱が発生し て長波長へシフトするが, ラマン光も同じようにコアに閉 じ込められて伝播するため,レーザー加工のようなパワー 応用加工には影響がない。

\section{3. ファイバレーザーの励起方式}

必要な励起密度を与えると,ファイバレーザーは理論効 率通りにレーザー光を発生する。問題は効果的な励起方 法とその拡大則にある. Fig.6に励起方式を示したが, コア 励起方式はチタンサファイアレーザーなどの高品質ビー ムで用いられるが, LD励起では不可能である.クフッド励 起は高効率で励起できる優れた方法であるが, 励起光の入 射断面積が狭いので，その拡大則に限界がある、V溝方式 は側面励起の形を取ったクラッド励起と見ることができ る. 入射端面をいくらでも増やせるので, 高出力が期待で きる。しかし，V溝からファイバが破断しやすい欠点を 持っている。（d）に示したファイバ結合によって励起光を 随時導入して行く方法は,ファイバ接合部の融着技術など がむずかしいが, 原理的に優れた方法である．高輝度ファ イバ結合型LDを一つの部品と考え, 単純に数を増やして, 高出力化を実現できる，LD，ファイバ伝送の特質を活かし た方法だといえる。これらは実用化され, 100W級の出力を 実現している，1kWを越える出力も実験室レベルで報告さ れているが, 方式上, 製造コスト面で難しい問題を抱えて いる.

一方, 高出力LDの技術からすると, 輝度は低いが安価に 高出力が実現できるLDバーやそのスタックを利用する方 法が考えられる．固体レーザーの励起入射面積は, 端面励

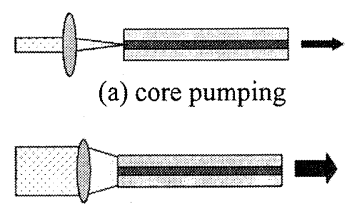

(b) clad pumping (c) V-groove pumping

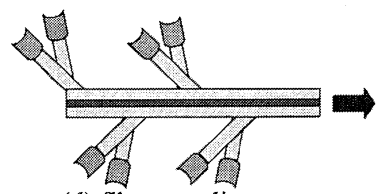

(d) fiber coupling

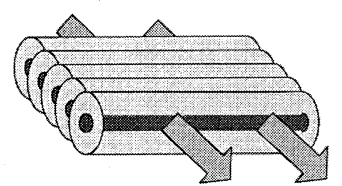

(e) side pumping
起より側面励起が必ず大きい. 直径を $d$, 長さをLとすれ ば, 側面・断面積比は $d L /\left(\pi d^{2} / 4\right) \approx L / d$ となるので, 長大な 長さを持つファイバレーザーは側面励起に適している. ではなぜ,ファイバレーザーの側面励起が試みられなかっ たのだろう。極細のファイバでは励起光の利用効率が低 くて, 実用にならないからだが,ファイバを重ねて (e)のよ うに光学厚さを増せば問題は解決する。ファイバで作っ たディスクや円筒は, 光学的に厚い構造を取りながら, 実 体は 1 本のファイバレーザーで構成することができる。 コ ア対クラッド比が $1 / 2$ のルチモードファイバで構成すれ ば, 実効的吸収率が $1 / 4$ のガラスレーザーと同等となる。今 後, 産業応用にはキロワット級の出力が必要とされるよう になる。その場合は，ファイバレーザーの側面励起4-7)が もっとも有望な方式となるだろう。 その具体例がFig.7に 見るようなファイバディスクレーザーで, 我が国で開発が 続けられている。この方式では, 励起光は平面導波路に閉 じ込められたまま,ファイバレーザーを励起するので, ク ラッド励起と同じ原理を保持し続けている.

\section{4. 高効率・高出カレーザーの条件}

レーザーの基本原理からファイバレーザーを再チェッ クしてみよう。最初に確認するべき事は, 完全飽和条件に おける高効率動作の可能性である.

もっとも単純なレーザー増幅の式を検討する.

$$
\frac{\mathrm{d} I}{\mathrm{~d} z}=\left(\frac{g_{0}}{1+I / I_{\mathrm{s}}}-\alpha\right) I
$$

は単位長あたりの光増幅, すなわち,レーザー媒質からレー ザー光にパワー供給される割合である。ただし,Iは入力パ ワー, $g_{0}, \alpha, I_{\mathrm{s}}$ は小信号利得係数, 損失係数, 飽和強度であ る.レーザー材料の損失は通常, 吸収で決まるので, 利得 損失比 $\gamma$ は $\gamma=g_{0} / \alpha$ 表されることが多い.しかし, 吸収が 少なく散乱損失が重要となるファイバレーザーでは, 従来 の表記法との接続性を考慮して, 非飽和損失全体を $\alpha$ とし て表現する，飽和強度 $I_{\mathrm{s}}$ は $I_{\mathrm{s}}=\frac{h v}{\sigma \tau}$ で決まるように, 光子工 ネルギー $h v$ と誘導放出断面積 $\sigma$, 上準位寿命 $\tau$ で決まるレー ザー媒質固有の量である。(1)式から,増幅媒質内に蓄積さ れたエネルギー(反転分布)からレーザー光に变換される効 率, 引き出し効率の最適条件 $\left(\frac{\partial}{\partial I}\left(\frac{\mathrm{d} I}{\mathrm{~d} z}\right)=0\right)$ を求めると, 最

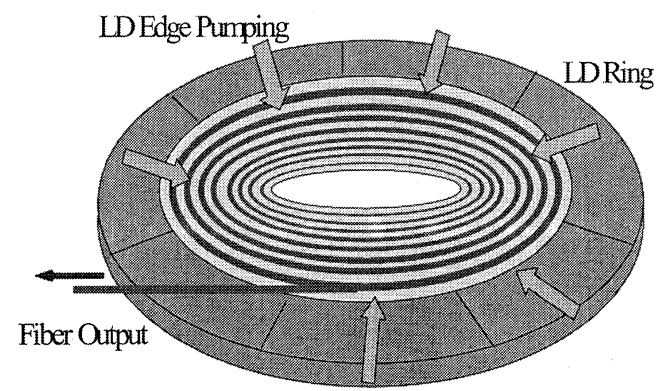

Fig.7 Edge pumping of fiber-embedded disk laser.

Fig.6 Various pumping schemes of fiber lasers. 
大引き出し効率を与えるレーザー入力は

$$
I_{\mathrm{opt}}=I_{\mathrm{s}}\left(\sqrt{\frac{g_{0}}{\alpha}}-1\right)
$$

一方, レーザー発振に関係する2準位間のエネルギーフ ローを考える．励起パワー密度を $R_{\mathrm{p}}$ とすると,レーザー上 準位に供給される励起パワー $R_{\mathrm{p}}$ と, 脱励起によって減少す るパワー $h v n_{0} / \tau$ は定常状態において平衡状態にある。たた し, $n_{0}$ は小信号利得を与える反転分布量である。これは小 信号利得状態でも, 完全飽和状態でも変わらない。した がって,

$$
R_{\mathrm{p}}=h v \frac{n_{0}}{\tau}=\sigma n_{0} \frac{h v}{\sigma \tau}=g_{0} I_{\mathrm{s}}
$$

の関係となって, 励起強度と小信号利得係数は比例関係に ある.（2）(3)式から最大効率を求めると,

$$
\eta_{\mathrm{opt}}=\frac{\left(\frac{\mathrm{d} I}{\mathrm{~d} z}\right)_{I=I_{\mathrm{opt}}}}{R_{\mathrm{p}}}=\frac{(\sqrt{\gamma}-1)^{2}}{\gamma}, \quad \gamma=\frac{g_{0}}{\alpha}
$$

の関係を得る。（4)式は, 引き出し効率が利得損失比 $\gamma=\frac{g_{0}}{\alpha}$ だけで決まる事を意味する，最適引き出し効率の 理論曲線をFig.8に示した. $\gamma=10$ 程度の弱い励起では, 最 大引き出し効率は $50 \%$ にも達しないことが分かる。これは レーザー一般を支配する原理であり, 損失のもっとも少な い媒質であるファイバレーザーは,レーザー材料に与えた 励起パワーをもっとも効率よくレーザー光に変換できる よいレーザーであることを示している。

最適効率動作を考える限り, ファイバレーザー, ロッド

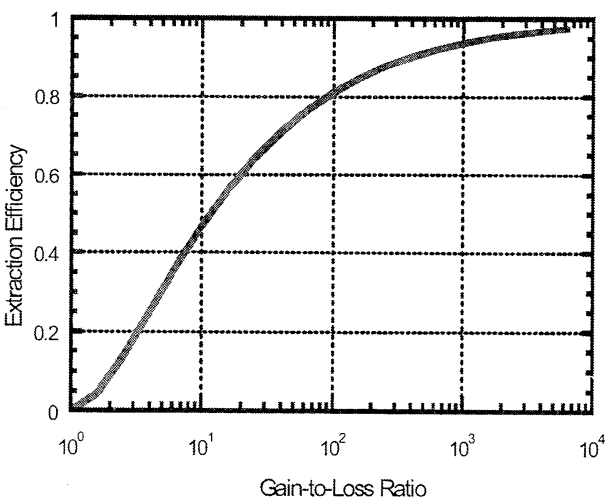

Fig.8 Extraction efficiency vs gain-to-loss ratio.
レーザー, スラブレーザー, 薄板レーザーのどれをとって も, 一定の出力を発生するのに必要なレーザー体積は同じ である. 最大出力を決定するのは最大励起入力であり, 入 力可能なパワーは, 冷却, 損傷, 破壊, 励起方式などの要因 で決まる．冷却や励起の拡大則はレーザー媒質の体積 · 表面積比で決まるので, 長尺のファイバ型とアクティブミ ラー型(薄板レーザー型)が高出カレーザーとして優れてい る。これは高出力レーザーが太いロッドやスラブで実現 されている現在の固体レーザーの常識と違うように見え るかも知れない. しかし, それはロッドやスラブ型のレー ザーの冷却効率が悪いため, 同じ熱流を実現するために, 大 きな熱勾配が必要となり, 結果として内部応力限界に達し ているからにすぎない.アクティブミラー型レーザーで はすでに高効率kW出力が実現8)しているが, ファイバレー ザーでは励起体積の100\%完全利用ができるので,さらに優 れた特性が期待できる。

前述の利得・損失比の考察からすると, 通常のレーザー が共振器内にロッドとミラーを別々に持ち, レーザー光が 往復する毎にロッド端面の反射, 散乱損失を受けているの は, 本来のレーザーからすれば, 無駄な損失である。長大 な利得長を持つファイバレーザーは, 回折損失を含め, 無 駄な共振器損失を持たないという点で, もっとも原理に忠 実なレーザーだということができる。 そして, それが高効 率発振の理論的根拠となっている.

\section{5. ファイバレーザーの将来像}

ラマンファイバレーザーでは, 各種ガラスのラマン利得 を利用して, 広い範囲の波長可変性を持ったレーザー光を 発生することができる。 その際, 利得内で任意の波長を高 効率に発生させるために有用なものがFBG (Fiber Bragg Grating)であり, 低損失で狭帯域の光共振器を実現できる. そのため, 高次ストークスであっても高効率ラマン発振9) が可能なので, 特に赤外領域における高輝度レーザー光源 として応用が期待できる.

これまで高出力ファイバレーザーはCW出力で発展して きた．極小のコア断面積は高出力を連続光で発生するこ とは許しても,パルスレーザーになるとレーザー損傷とい う困難な問題が発生する。しかし, 最近では, パルスレー ザーの要求, 特にサブピコ秒のモードロックレーザー出力 の要求 ${ }^{10,11)}$ が厳しくなってきた。そして, 応用が始まれ ば, 次第に高出力の要求が強まることは避けられない.

ファイバレーザーの特質に帍って考える。ファイバ

Table 1 Properties of solid state lasers.

\begin{tabular}{lccccc}
\hline \hline & Cooling & Pump input area & $\begin{array}{c}\text { Gain-to-loss } \\
\text { ratio }\end{array}$ & $\begin{array}{c}\text { Spatial mode } \\
\text { control }\end{array}$ & $\begin{array}{c}\text { Volume } \\
\text { availability }\end{array}$ \\
\hline Rod & $\times$ & $\bigcirc$ (side pump) & $\triangle$ & $\times$ & $\triangle$ \\
Slab & $\triangle$ & $\bigcirc$ (side pump) & $\triangle$ & $\times$ & $\bigcirc$ \\
Thin disk & $\bigcirc$ & $\triangle$ (end pump) & $\triangle$ & $\times$ & $\times$ \\
$\begin{array}{l}\text { Clad-pumped } \\
\text { fiber laser }\end{array}$ & $\bigcirc$ & $\times$ (clad pump) & $\bigcirc$ & $\bigcirc$ & $\bigcirc$ \\
$\begin{array}{l}\text { Side-pumped } \\
\text { fiber laser }\end{array}$ & $\bigcirc$ & $\bigcirc$ (side pump) & $\bigcirc$ & $\bigcirc$ & $\bigcirc$ \\
\hline \hline
\end{tabular}


レーザーはLD光を吸収し,それを高輝度のレーザー光に変 える高効率ビーム品質変換器である。パルス発振に利用 する場合には, レーザー媒質のエネルギー蓄積, 超短パル ス発振の特徵を利用するべきで, ファイバレーザー励起固 体レーザーの組み合わせが研究されるだろう。実際,パル ス圧縮をテーパー型ファイバで行うこともできるし， Chirped PPLN (Periodic Poled Lithium Niobate)結晶中12)で 行うこともできる。超短パルス生成で開発されたCPA (Chirped Pulse Amplification)の考えは,ファイバレーザー を使ってパルス出力を取り出すときに参考になる.

もちろん，もっと革新的な技術を使って，ファイバレー ザーが超短パルスを発生するようになることも期待でき る. 光ファイバが光をコア内に閉じ込めて伝播させてい るが, クラッド内に様々な規則的屈折率分布を形成するこ とにより,光伝播を人工的に制御するフォトニックファイ バ13,14)の開発が進んでいる. 光通信の分野では, 群速度分 散補正など, 超広帯域光通信を目指した研究が盛んで, フォ トニックファイバはクラッド内に広がった光電界を制御 している。モード体積の大きな単一モード光伝播を応用 すれば,パルス発振の高出力化に有利となる。これらの研 究は, ある意味で大学における手作りの研究技術が生み出 した新しい技術ということもできる．最先端を切り開く には, 最新技術のみでなく, 基礎的な考察に基づいたアイ デアを生み出すための頭脳作業が必要である。その意味 で, 大学と企業が各々の特長を生かす研究を要求される好 例となっている.

空間モードの制御には, マルチコアファイバ間のエバ ネッセント結合も利用できる。モノサイクル近くの超短 パルスで, パルス内電界の位相制御15)ができるようになっ てきた。空間的に離れたレーザー発振器間の位相制御は 次世代の課題だが, ファイバレーザーは2次元フォトニック 結晶として, その最前線に立ちうるレーザーだと考えられ る。

\section{6. おわりに}

高出力ファイバレーザーは従来の光通信ファイバレー ザーの常識を打ち破るところから発達した。そして, 実際 に高出力レーザーとしての産業応用が始まろうとしてい る.しかし,ファイバレーザーそのものの可能性は,さら に広い分野に広り゙ることができる，それは光伝播の完全 制御と,それらの理論的な特性を実現させる低損失特性に 起因している。巨視的なサイズで作りあげた断面形状が, そのままミクロな形状に保存されるというファイバ生成 のメカニズムは, 新しいフォトニックファイバも実現し た。これらの新しい知識と技術を応用すれば, 産業応用の みならず,科学応用においても大きな可能性が広がってい る. 現代のレーザー技術の最先端を担うファイバレー ザーの現状とその発展の根拠を紹介した。我が国におけ るファイバレーザー研究が発展することを期待する.

\section{参考文献}

1) H. Po, J. Cao, B. Lalibertee, R. Minns, R. Robinson, B. Rockney, R. Tricca, and Y. Zhang: Electron. Lett. 17 (1993) 1500.

2) V. Dominik, S. MacCormack, R. Waarts, S. Sanders, S. Bicknese, R. Dohle, E. Wolak, P. Yeh, and E. Zuker: CPD11, CLEO'99, Baltimore (1999).

3) A. Liu and K. Ueda: Opt. Comm. 152 (1996) 511.

4) 劉 安平, 亀谷幸一, 植田 憲一：レーザー研究 25 (1997) 702.

5) K. Ueda and A. Liu: Laser Physics 8 (1998) 774.

6) K. Ueda: Laser Resonators, Chapter 6 Optical Cavity for High Power Fiber Lasers (edited by Kudryashov \& Weber, SPIE Press, 1999) p.125.

7) K. Ueda: Jpn-Patent, No.9-174450 \& No.9-289851

8) A. Giesen: WeA1-14, Laser Optics 2000, St. Petersburg, June 28 (2000).

9) M. Prabhu, N. S. Kim, and K. Ueda: Opt. Comm. 182 (2000) 305.

10) 植田 憲一：レーザー研究 27 (1999) 805.

11) 三澤弘明：レーザー研究 27 (1999) 817.

12) M. Fermann, A. Galvanauskas, M. Stock, K. Wong, D. Harter, and Goldberg: CPD9, CLEO'99, Baltimore (1999).

13) M. J. Gander, R. McBride, J. D. C. Jones, T. A. Birks, J. C. Knight, P. St. J. Russell, P. M. Blanchard, J. G. Burnett, and A. H. Greenaway: Opt. Lett. 24 (1999) 1017.

14) N. Broderick, T. Monro, P. Nennett, and D. Richardson: Opt. Lett. 24 (1999) 1395.

15) A. Apolonski, A. Poppe, G. Tempea, Ch. Spielmann, Th. Udem, R. Holzwarth, T. Hansch, and F. Krausz: Phys. Rev. Lett. 85 (2000) 740 . 